\title{
The Cathedral of Pisa, (Continued), and Notes upon Pisan Churches
}

\section{J. H. Parker C.B.}

To cite this article: J. H. Parker C.B. (1878) The Cathedral of Pisa, (Continued), and Notes upon Pisan Churches, Archaeological Journal, 35:1, 353-359, DOI: 10.1080/00665983.1878.10851835

To link to this article: http://dx.doi.org/10.1080/00665983.1878.10851835

里 Published online: 14 Jul 2014.

Submit your article to this journal

Q View related articles $₫$ 
THE CATHEDRAL OF PISA,

(CONTINURD),

\section{AND NOTES UPON PISAN CHURCHES.}

By J. H. PARKER, C.B.

My former notice ${ }^{1}$ of this fine and interesting Cathedral is not complete without some further particulars, in confirmation of my views, and some mention of other churches in the town connected with it. I made a slight mistake about the campanile, which is an important part of the evidence about the dates; I said it was founded in 1174, which is true, but I went on to say that the work was continued for sixty years. I ought to have said it was suspended for sixty years, in consequence of the foundations having given way on one side to the depth of six feet when the ground floor only had been built. The work was resumed in 1234, just sixty years after the foundation, and there is a marked difference in the construction and style of this work between the ground floor and all above it (excepting of course the upper storey of all with the roof, which is quite a century later); the ground floor is of the Italian Romanesque, corresponding to the Norman in England. The next six floors have the light and elegant arcades and colonettes, or what we call shafts, exactly similar to those of the west front. Then also, in all above the ground floor there is no perceptible difference in these five floors of the campanile; the work seems to have gone on steadily, for probably thirty years from 1234. The reason the ground floor of the present west front of the cathedral is also of earlier character than the upper part is, that it is built of the materials of the old west front, to which the arcades certainly did not belong. A contract is extant for building the cathedral at a still earlier period than Pope Gellasius, by an architect named Buschetto or 
Boschetto, who is said to have come from Byzantium, and to have gone to Rome to fetch columns and other materials, as the old buildings of the empire in Rome served for quarries of marble for all Italy. Among other things he appears to have brought a sarcophagus for himself to be buried in; and there is an excellent engraving of this sarcophagus in M. Rohault's work, as "the Tomb of Boschetto," with an inscription upon it giving the date of 1016 as the year of lis death.

In M. Rohault's ground plan of the cathedral there does appear to be three periods in the walls. The eastern apse being the earliest, and that is precisely the part which is built of old Roman materials. Mr. Irvine has very carefully reproduced this plan for me; also the west front and the elevation of one side. ${ }^{1}$ The three photolithographs give the architectural history very clearly. In the ground plan the original west front is distinctly shewn, and in the elevation at the same point there is a straight vertical joint in the wall, shewing that the wall beyond this, westward, is later than the rest of the church. In the west front also the difference between the solid ground floor and the light arcades of the upper part comes out very distinctly. Some other churches in the town also throw light on the history of the cathedral.

But I will first treat of the Baptistry, which, though quite detached from the cathedral locally, is necessarily connected with it historically. This was founded in 1153 , but again only the ground floor is of that period, and it is very beautiful Italian Romanesque, especially the rich doorway, of which M. Rohault gives one of his beautiful engravings; but here again the work was suspended for a long time for want of funds, and was resumed in 1278, as is recorded by an inscription, and then it seems to have gone on very slowly, for the greater part of the work is evidently of the fourteenth century, as may be seen by comparing it with the Campo Santo, where the dates of different parts of the cloisters are recorded by inscriptions; part of it was founded in $1278 .^{2}$

This work corresponds in style with work of the same

${ }^{1} \mathrm{~A}$, is the oldest part ; $\mathrm{B}$, the second period ; $C$, the additions at the west end ; $\mathrm{D}$, modern.
${ }^{2}$ A.D. M.CC.LXXYII. Tempore Domini Federici Archi-Episcopi Pisani, et Domini Terllati Potestatis. Operario Orlando Sardella; Johanne Magistro edificante. 


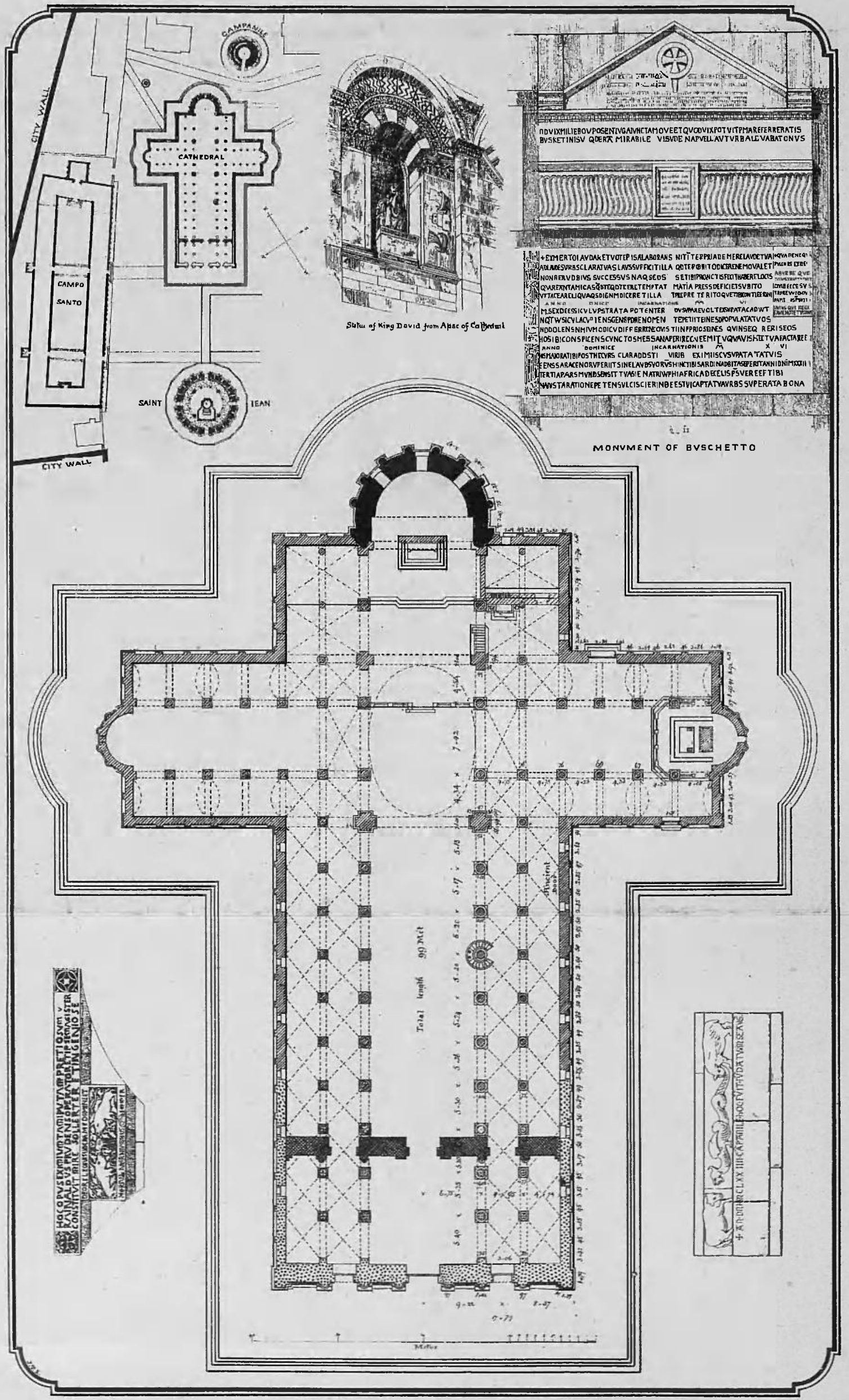




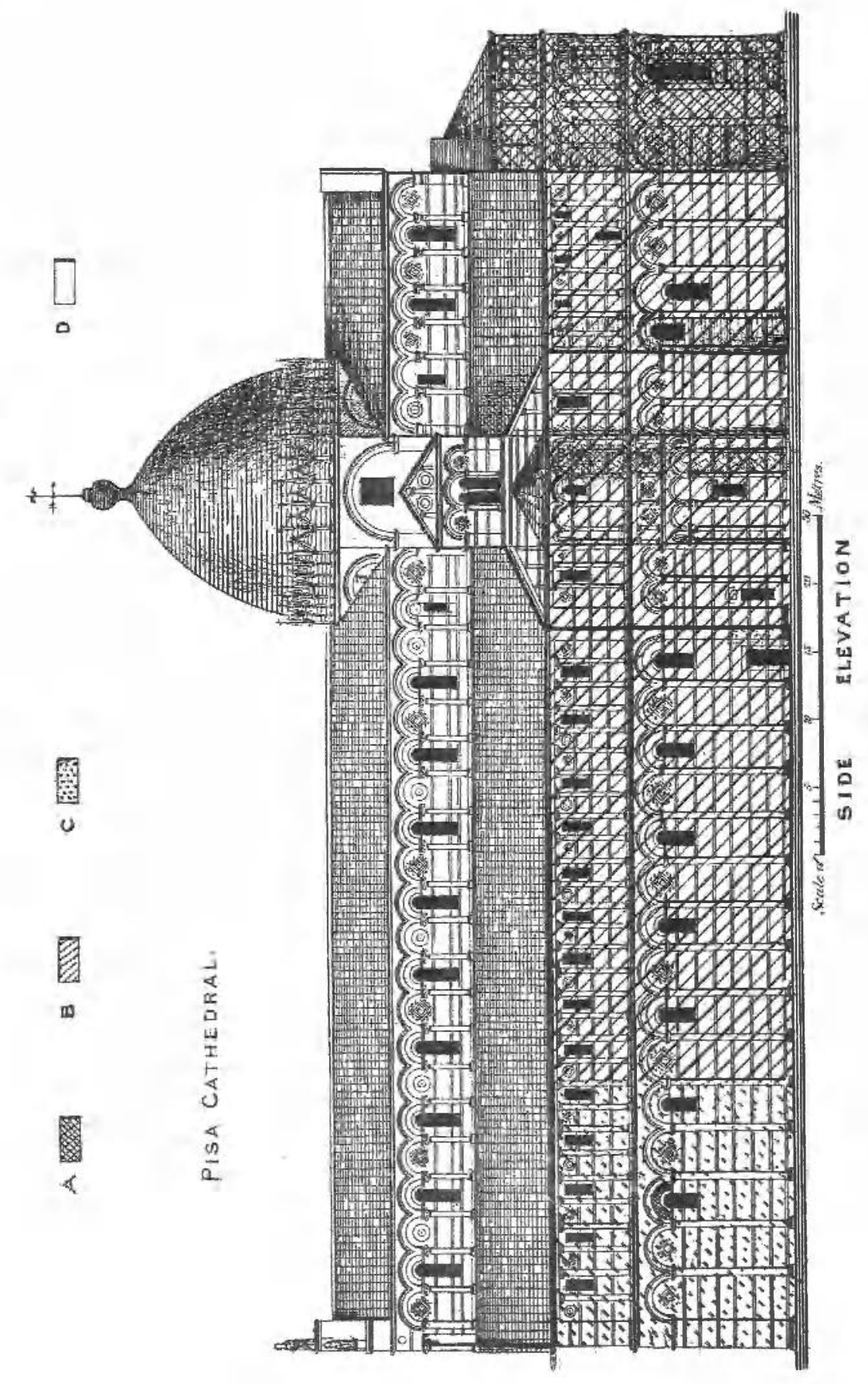




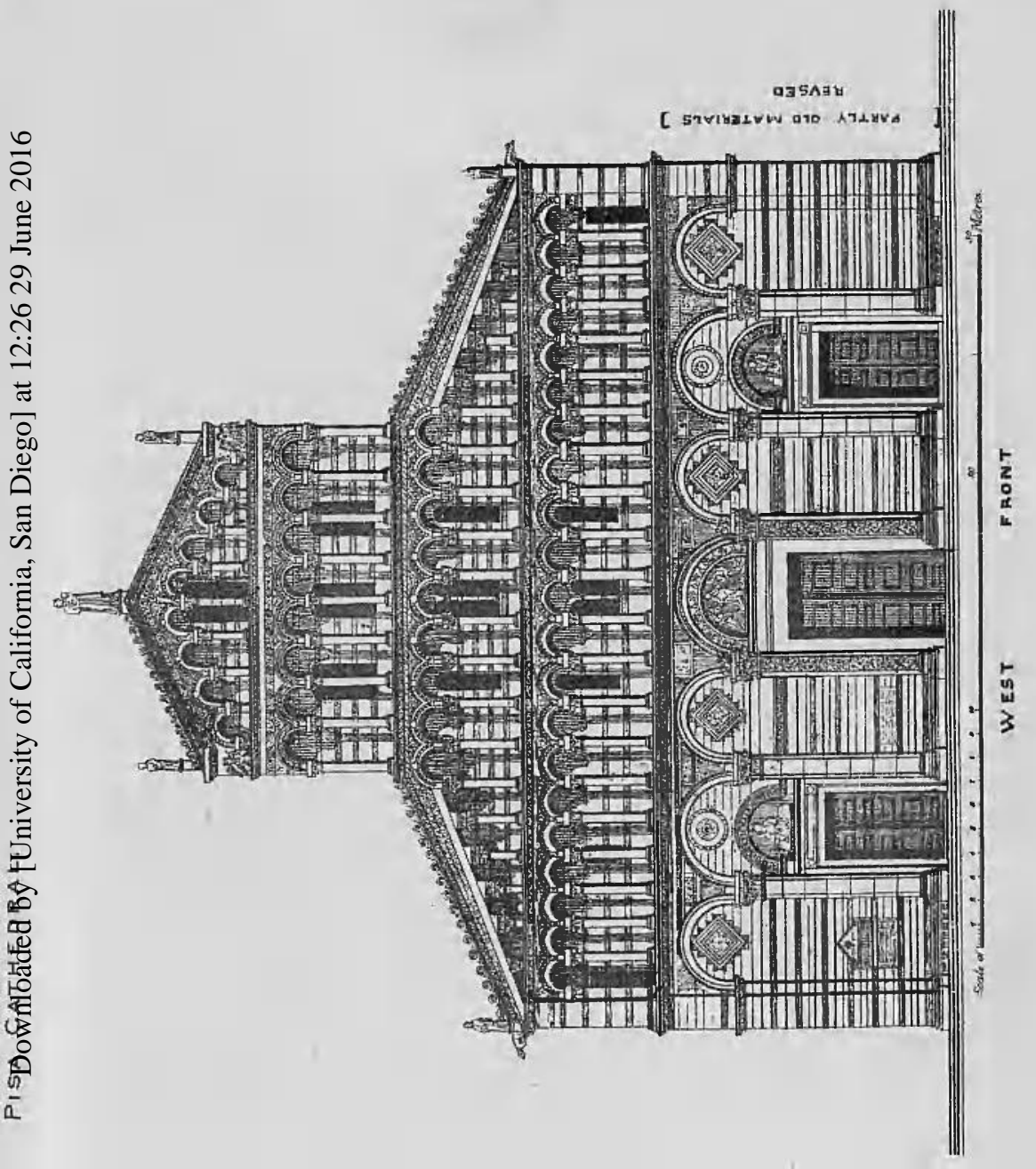


period in England. This was the work of John of Pisa, who died in 1320 .

The other churches in the town throw light on the architectural history of the cathedral, or chief church, by the principle of comparison, as is usual evergwhere. There are several good churches in Pisa of the twelfth century, and others of the thirteenth, of which engravings are given by M. Rohault. Some of these are beautiful examples of their respective periods, and they are generally dated historically or by inscriptions; but their style of architecture is not in advance of that of other countries, including England, at the same time. The sculptured ornament is more beautifully executed, for the Italians are hereditary sculptors, and were perhaps in advance of any other country in sculpture after the fall of the Roman Empire, excepting the Byzantine Greeks, whose work does not bear on the question.

At Pisi, the west front of the Church of St. Paul (San Paolo a ripa) is that of the cathedral in miniature, and the tradition is that it was the type followed by the architect, or rather that it is by the same designer; the facts sustaining the correctness of the tradition are very remarkable. Here also the lower story is quite different in character from all above it. This lower west wall is dated by an inscription upon it, in the interior, A.D. 1195.' In this instance the inscription is cut on part of the original construction. The date agrees well with the character of the arcades of the nave, which have pointed arches in the style which, in England, would be Transitional Norman. There is another inscription in the eastern part of the church, but this part has been rebuilt, and the inscription built in from the old wall, as at the cathedral. The upper part of the west front is a series of three of the elegant arcades of the thirteenth century. But there is a palpable difference in the construction of the wall in all above the ground floor.

San Frediano, founded in 1007, is perhaps really of the eleventh century, although probably half a century in construction, and if so is in advance of England or of the north of France, at that period. The

'By some accident the two inscriptions in this church have escaped the notice of M. Rohault in his excellent work. 
west front is good, but simple and plain, and it has four small round holes, two over the west window, and in the gable of that end, and one in the sloping lean-to roof of the aisle on each side, probably to give air to the timbers of the roof, a wise precaution, often neglected in England; but the small round holes do occur in English churches of the eleventh century. There is here the shallow external panelling, resembling arches built in, which is a good Italian feature, not often met with elsewhere.

The Church of St. Peter (San Pietro-a-grado) is a good and simple Romanesque church, with a semi-détached campanile, of the early part of the, twelfth century. M. Rohault gives the date of 1100 to it, and this may be the time when it was begun, but it would take some years in building. The style is too light for the earlier date. It has three apses at the east end, and one at the west, with side walls and slender piers to the aisles. This cannot be very early in the twelfth century.

San Agatha is attributed to A.D. 1063. It is a singular structure, a small octagonal chapel, with an acute pyramidal roof. The windows, one in each bay, are of two lights, with slender shafts; over each is one of the small round holes before mentioned. The walls are built of brick, after the Roman fashion, but not of Roman bricks. The mouldings and the capitals agree with the latter part of the eleventh century.

St. Sepulchre is one of the octagonal churches, built in imitation of the Church of the Holy Sepulchre at Jerusalem by the Crusaders, after their return. They were generally built by the order of the Knights Templars, and were for the most part erected after A.D. 1187. This is a small octagonal building, with a small central space, and wide aisle round it, and a conical roof over the central part only; the aisles have nearly flat lean-to roofs. There is a good Romanesque campanile, of light character, detached, but almost touching the church; and in the lower part of the wall of this is an inscription-

"VIVIS OPERIS FABRICATOR.

DSTE SALVETR. MINAT."

giving the name of Deodatus Salvi as the builder; the same name occurs in the wall of the Baptistry of the 
time of the foundation, 1153, in another original inscription. We may, therefore, safely assign this Church of the Sepulchre to the latter half of the twelfth century. It has acutely-pointed arches, of the transitional character, and all the details agree with this.

One of the towers in the wall of the town is of the same transitional character, and was evidently inhabited.

The church of St. Nicholas is attributed to the celebrated architect, Nicholas of Pisa, the founder of the Pisan School. He is said to have had great influence during his life, and built churches at Venice, Siena, Pistoia (this one dated A.D. 1240), and Florence, as well as in Pisa, where we have, besides this church of his name, those of St. Catherine and St. Francis. St. Nicholas has a detached campanile, octagonal in plan, with shallow external panelling, a very light roundheaded arcade, and a small octagonal pyramidal roof. The west front would be called in England late Norman, because the external panels and the windows are all round-headed ; but it is here called Gothic, and justly so, for the details are of that style. The foundations of the campanile have given way a little on one side, making another leaning tower, but here, as at the cathedral, and, long before that time, at the Muro Torto, in Rome, the builders have gone on with the work, not alarmed by the leaning over.

St. Catherine is more decidedly Gothic in character ; in the lower part the panels are round-headed, but in the upper part the arcades are pointed and very elegant Gothic. It has a square east end and aisles to the chancel only; the nave is long and narrow, without aisles, but with four altars on each side against the walls.

St. Francis, by the same architect, also has a square east end, with side aisles to the chancel only, and a long narrow nave. There are seven altars against the east wall, after the same fashion as the nine altars at Durham, of about the same period, but here there are also four altars on each side of the nave. There is a cloister against the north wall, and a chapter house at the end of the north transept.

John of Pisa, the son of Nicholas, inherited all the talent of his father, and for some years they worked 
together: at Cortona their names are mentioned in the same inscription in the wall of the campanile of St. Margaret.

The Spina at Pisa is considered as the masterpiece of John of Pisa, and is an exquisite little gem, but much mutilated. M. Rohault has restored it on paper admirably, but in reality it has suffered very much from illusage of all kinds. It is built in the bed of the River Arno, against the bank, by the side of a street, which is a great thoroughfare. It is said to have been built in 1230 , by the citizens of Pisa, enthusiastically, to receive one of the spines of the crown of thorns. The great floods of the river have damaged it more than once, and the malice of ignorant men also ; but the bad restorations attempted have perhaps injured the architectural character more than anything else. 'The latest restoration is said to have really restored it, in a great degree, to its pristine beauty. M. Rohault's excellent drawings at least show what it has been. At the east are three small octagonal spires, surmounted by figures, standing on beautiful capitals. At the west end are five pinnacles, with figures under canopies in them, the back grounds left open, and on the top of the two outer ones are other figures standing upon the canopies. It was an exquisite little gem, and, as M. Rohault says, deserves to have been kept under a glass cover.

The Campo Santo has been mentioned as being of two periods. It is called the last glory of the Pisan Republic, and was founded in 1278, as recorded by an inscription, in which John of Pisa is mentioned as Magister Operum. Some records say that it was very long in building; it is a beautiful and lofty cloister, full of tombs. The original windows are among the most valuable of the period. They are of four lights, divided by slender shafts, with trefoils and quatrefoils in the heads ; they correspond to the cloister and chapter house of Salisbury, but are lighter. The walls have the Italian shallow panelling, the panels being round-headed; but this is usual in Italian Gothic. Over the door is a beautiful set of niches and canopies, over a group of sculpture of the adoration of the Magi. M. Rohault gives a plan of the cloister, and details of this beautiful burial ground. 
The Church of St. Michael has the same feature of a group of sculpture, under canopies corbelled out over the doorway, and the style of art is so much the same, that it must be of the same period as the Campo Santo, the end of the thirteenth century - the time of our beautiful buildings and crosses of Edward I. and Merton College Chapel; but at that time Pisa was certainly not in advance of style over England. There is a crypt under this church, with some original painting in the vault, of which M. Rohault gives an engraving. $\mathrm{He}$ also gives a series of beautiful engravings of Pisan sculpture; but these belong to another subject. 